\title{
Koronawirus a bezpieczeństwo zabiegów okulistycznych. Najczęściej pojawiające się pytania i wątpliwości
}

\author{
Coronavirus and the safety of ophthalmic procedures. Frequently asked questions
}

\author{
Wywiad z prof. dr. hab. n. med. Markiem Rękasem, \\ konsultantem krajowym ds. okulistyki \\ Interview with prof. dr. hab. n. med. Marek Rękas, \\ Polish national consultant for ophthalmology
}

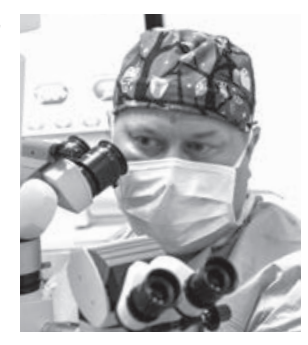

Istotnymi cechami gatunkowymi koronawirusów, w tym wywołującego obecną pandemię szczepu 2019-nCoV, są duża odporność na warunki środowiskowe oraz zdolność do przetrwania $w$ postaci aerozolu. Powoduje to wiele trudności w planowaniu i wykonywaniu różnego rodzaju zabiegów. Sami lekarze niejednokrotnie stają wobec dylematu, czy mogą przeprowadzić daną procedurę bezpiecznie dla pacjenta i dla siebie. $Z$ tego powodu towarzystwa medyczne i konsultanci $z$ różnych dziedzin medycyny przygotowują wytyczne określające zasady prowadzenia leczenia w tym trudnym czasie. Czy w Polsce odnośnie do wykonywania zabiegów okulistycznych $w$ okresie zagrożenia zostały wprowadzone podobne unormowania? Co mówią one o możliwości przeprowadzania zabiegów u pacjentów i czy wprowadzają jakieś ograniczenia?

W porozumieniu z Głównym Inspektoratem Sanitarnym i za zgodą Ministerstwa Zdrowia opracowałem wytyczne, które uregulowały wykonywanie świadczeń przez wszystkie podmioty świadczące usługi medyczne z zakresu okulistyki, czyli zarówno lekarzy okulistów, jak i optometrystów. Są one na bieżąco aktualizowane stosownie do rozwoju sytuacji epidemicznej w kraju. Na początku, gdy epidemia się rozwijała, wykonywane były tylko procedury dotyczące pilnych przypadków i sytuacji, gdy leczenie nie mogło zostać przerwane, czyli terapia zwyrodnienia plamki związanego z wiekiem (AMD, age-related macular degeneration), iniekcje doszklistkowe przy cukrzycowym obrzęku plamki (DME, diabetic macular edema), odwarstwienie siatkówki, niektóre przypadki zaćmy. Od 1 maja natomiast, wraz z ogólnym zmniejszeniem reżimu sanitarnego w Polsce, dopuściliśmy również wykonywanie zabiegów planowych i prowadzenie normalnej praktyki leczniczej, ale pod warunkiem zachowania dystansu społecznego $(2 \mathrm{~m})$, zachowania zasad higieny i stosowania środków ochrony osobistej przez lekarza i przez personel medyczny. Środki ochrony dzielimy na cztery grupy:

1. fartuch jednorazowy, nieprzemakalny z długim rękawem

2. rękawice ochronne jednorazowe

3. maska chirurgiczna, maska FFP2 i FFP3 lub równoważna N95, N99

4. przyłbice ochronne, gogle, okulary ochronne.

W przypadku dużego zagrożenia (pacjent podejrzany, pilny z kontaktem z powierzchnią oka) należy użyć środków ze wszystkich czterech grup, natomiast w sytuacjach małego zagrożenia (wizyta planowa bez kontaktu z powierzchnią oka) wystarczy zastosowanie środków z grup drugiej i trzeciej. 
Jeśli chodzi o zasady higieny, to lekarz musi dezynfekować ręce przed kontaktem i po kontakcie z każdym pacjentem. Nie powinien dotykać nosa, ust ani twarzy rękami. Musi także pamiętać o używaniu rękawiczek jednorazowych przy otwieraniu drzwi, używaniu lampy szczelinowej itp. Po użyciu rękawiczek należy je wyrzucić. Sama wizyta nie powinna trwać dłużej niż $15 \mathrm{~min}$, a wywiad powinien się odbywać z zachowaniem dystansu społecznego. Badanie w lampie szczelinowej powinno trwać jak najkrócej i odbywać się w milczeniu (pomimo obecności osłon na urządzeniu). Po każdej wizycie należy zdezynfekować klamki i powierzchnie dotykowe środkiem dezynfekującym. Trzeba także zwrócić uwagę na dezynfekcję przyborów do pisania, klawiatury i innych akcesoriów, z którymi miał kontakt lekarz lub pacjent. W przypadku konieczności przyjęcia pacjenta do szpitala należy się upewnić, że nie jest on zakażony koronawirusem. Służy temu wielopoziomowy system kwalifikacji oparty na wywiadzie.

\section{Na czym on polega?}

Wielopoziomowa kwalifikacja polega na przeprowadzaniu wywiadu zdrowotnego u pacjenta na każdym etapie kwalifikacji do leczenia: telefonicznie, przy wejściu do budynku, na poziomie rejestracji i w gabinecie. Ma ona na celu zminimalizowanie ryzyka kontaktu z osobą zakażoną koronawirusem.

Sama procedura wywiadu została określona w dołączonym do wspomnianego stanowiska formularzu ankiety wstępnej. Pacjenta pytamy o pobyt w regionach, w których występuje podwyższona zachorowalność na koronawirusa, i o to, czy był poddany kwarantannie. Następnie prosimy o informacje dotyczące występowania podstawowych objawów infekcji koronawirusem, czyli na temat podwyższonej temperatury, występowania kaszlu, ogólnego samopoczucia, duszności, oraz pytamy o ewentualny kontakt z osobą zakażoną. Niezależnie od tego, zgodnie z decyzją wojewodów, każdy pacjent musi mieć zmierzoną temperaturę.

Jeżeli nie stwierdzamy żadnych objawów, pacjent jest dopuszczony do operacji, w przeciwnym przypadku musi zostać odizolowany. Postępujemy wówczas zgodnie z wytycznymi w danym ośrodku, czyli zwykle robimy test i pacjent jest ewentualnie odsyłany do sanepidu.

Poruszył Pan Profesor zagadnienie minimalizacji ryzyka kontaktu z osobami zakażonymi. Jednym ze sposobów na to jest prowadzenie telewizyt kontrolnych. Pozwalają one pozostać pacjentowi $w$ domu i uniknąć kontaktu $z$ innymi pacjentami w poczekalni. Lekarze jednak miewają kłopot z telewizytami. Nie są bowiem pewni, czy i w jaki sposób mogą je rozliczyć. Czy są jakieś wytyczne, które pozwoliłyby zyskać jasność w tej materii?

Zasady finansowania większości telewizyt wykonywanych w ramach ambulatoryjnej opieki specjalistycznej są takie, że każda tego typu wizyta jest płatna zgodnie z ustaleniami Narodowego Funduszu Zdrowia.

Nieco inaczej sytuacja wygląda w przypadku leczenia zaćmy. Przypomnę, że w tym przypadku Narodowy Fundusz Zdrowia płaci za cały proces leczenia, a zatem za zakwalifikowanie pacjenta do operacji, operację oraz kontrolę po zabiegu. Zwykle wystarczała jedna wizyta kontrolna między 14. a 28. dniem po operacji. Jednak w wielu przypadkach ośrodki przeprowadzały więcej wizyt, żeby zmniejszyć ryzyko powikłań. Podkreślam, że takie nadplanowe wizyty nie były i nie są dodatkowo płatne. Zalecamy, aby wizyty powyżej pierwszej kontroli były wykonywane za pomocą różnych środków telekomunikacji (telefonicznie, przez komunikatory). 
Panie Profesorze, mimo sformułowania wytycznych dotyczących bezpieczeństwa i wdrożenia działań mających zapobiegać zakażeniom u niektórych lekarzy i pacjentów nadal występuje lęk przed wykonywaniem zabiegów w czasie pandemii. Może się to przekładać na mniej lub bardziej świadome odwlekanie przez lekarza wykonania zabiegów, które wydają mu się mniej pilne. Także pacjenci obawiają się, że podczas procedury lub późniejszego pobytu w szpitalu mogą zakazić się koronawirusem. Czy są przypadki, w których pacjenci powinni być bezwzględnie i pilnie kierowani na zabiegi okulistyczne?

Na przedstawiony problem musimy spojrzeć z dwóch punktów widzenia: pacjenta i lekarza. Jeśli chodzi o pacjenta, to ostateczna decyzja o wykonaniu zalecanego zabiegu należy przede wszystkim do niego, i to niezależnie od pilności procedury czy stanu zdrowia. Jeśli pacjent nie zgadza się na proponowane leczenie, czy to z obawy przed zakażeniem koronawirusem, czy też $\mathrm{z}$ innego powodu, to jest to decyzja, którą lekarz musi uszanować.

Natomiast z punktu widzenia lekarza decyzja o rozpoczęciu danego leczenia powinna opierać się na wskazaniach klinicznych. Dotyczy to zwłaszcza sytuacji pilnych, których listę zawiera wspominane tu stanowisko.

1. Pilne zabiegi chirurgiczne:

- uraz oka

- odwarstwienie siatkówki i pilne przypadki z zakresu chirurgii witreoretinalnej

- leczenie jaskry

- leczenie nowotworów

- transplantologia okulistyczna

- leczenie AMD

- leczenie DME

- zabiegi w zakresie aparatu ochronnego oka uniemożliwiające funkcjonowanie pacjenta

- zabiegi usunięcia zaćmy:

- zaćma wrodzona zagrażająca rozwojem niedowidzenia

- zaćma u pacjenta jednoocznego utrudniająca codzienne funkcjonowanie (prowadzenie pojazdów, czytanie itp.)

- zaćma zagrażająca ostrym zamknięciem kąta tęczówkowo-rogówkowego

- usunięcie soczewki w ostrych powikłaniach soczewkowych (podwichnięcie soczewki własnej, jaskra wtórna pourazowa, zaćma pęczniejąca)

- różnowzroczność po operacji oka towarzyszącego utrudniająca codzienne funkcjonowanie

2. Pilne zabiegi zachowawcze:

- zespół czerwonego oka

- uraz oka

- ciało obce

- nagłe pogorszenie widzenia

- ból oka

- ropne schorzenia aparatu ochronnego oka, dróg łzowych i rogówki

- zaostrzenie przewlekłych schorzeń okulistycznych

- diagnostyka retinopatii wcześniaków

- przewlekłe choroby oka.

Musimy pamiętać, że mimo szczególnej sytuacji, w jakiej przyszło nam działać, nadal obowiązuje nas postępowanie zgodne z ustawą o zawodzie lekarza. Mówi ona jasno, że w przypadkach, gdy pacjent wymaga pomocy (zwłaszcza pilnej), to nawet jeśli lekarz nie dysponuje odpowiednimi zabezpieczeniami, musi tej pomocy udzielić. Później, oczywiście, może zgłosić swoje roszczenie wobec pracodawcy. To sytuacja trochę jak w wojsku: najpierw trzeba wykonać obowiązek, a później można dochodzić swoich praw. 
W przypadku zabiegów może istnieć pokusa ich odłożenia ze względu na pandemię. Przestrzegałbym jednak przed podejmowaniem zbyt pochopnych decyzji w tym zakresie. Przede wszystkim pamiętajmy, że koronawirus nie zniknie za miesiąc czy dwa, ale będzie z nami jeszcze bardzo długo. Niektórzy eksperci twierdzą, że stan epidemii potrwa co najmniej rok, może nawet dwa lata. Nie widzę powodu, aby odraczać zabiegi planowe, dlatego jeśli pacjenci się zgłaszają, to należy je wykonywać. Planowe zabiegi zaćmy, refrakcji laserowej i innych powinny być przeprowadzane w sposób zaplanowany przed epidemią, ale z zachowaniem środków ostrożności, jak: dystans społeczny, częste mycie rąk, zabezpieczanie się maseczkami. Kierownictwo placówki może podjąć decyzję o zmniejszeniu przepustowości sal operacyjnych. W wytycznych zaznaczyłem, że może ona stanowić 50-70\% obrotu przeciętnej sali operacyjnej. Nie ma jednak przeciwwskazań, żeby stanowiła 100\% takiego obrotu, jeśli tylko możliwe jest zapewnienie dystansu społecznego. Tak jak chodzimy do sklepu, tak w szpitalu stykamy się z innymi. Oczywiście musimy zachować ostrożność.

Zmniejszenie częstotliwości bezpośrednich kontaktów z pacjentem przed operacją i mniejsza liczba zabiegów na sali operacyjnej prowadzą do wydłużenia czasu, który można przeznaczyć na przygotowanie pacjenta do zabiegu w dniu operacji. Czy w związku z tym należy stosować tradycyjną, kroplową mydriazę?

Pacjent $\mathrm{w}$ ramach przygotowania do operacji zaćmy 3-4 razy dostaje krople w celu uzyskania rozszerzenia źrenicy. To powoduje z jednej strony dodatkowy kontakt z personelem, a z drugiej - przedłuża czas pobytu chorego w szpitalu. W obecnej sytuacji obie powyższe kwestie powinny być zredukowane tak bardzo, jak tylko jest to możliwe. Dlatego w chirurgii zaćmy zalecane jest śródoperacyjne uzyskanie mydriazy, a tym samym rezygnacja z tradycyjnej metody kroplowej.

\section{Jaki sposób mydriazy jest rekomendowany w przypadku operacji wykonywanych w znieczuleniu okołogałkowym?}

W przypadku zastosowania znieczulenia pozagałkowego wykonywanego podczas operacji może dochodzić do rozszerzenia źrenicy pod jego wpływem i w efekcie dodatkowe śródoperacyjne rozszerzanie źrenicy może nie być potrzebne. Znieczulenie okołogałkowe nie ma wpływu na źrenicę i tu można stosować mydriazę śródoperacyjną. Znieczulenie pozagałkowe i okołogałkowe wiążą się jednak z możliwością wystąpienia działań niepożądanych i dlatego są zarezerwowane dla ściśle określonej grupy pacjentów. Standardem znieczulenia w zabiegach usunięcia zaćmy jest znieczulenie kroplowe.

Istnieje także możliwość uzyskania jednoczesnego, śródoperacyjnego znieczulenia i mydriazy, co redukuje kontakt z personelem oraz skraca czas pobytu pacjenta w szpitalu, tym samym zwiększając bezpieczeństwo w tej procedurze.

Jakie w obecnej sytuacji epidemiologicznej są rekomendacje i zalecenia dotyczące stosowania antybiotyków przed zabiegiem usunięcia zaćmy, w jego trakcie i po jego zakończeniu?

Ze względu na dążenie do ograniczenia kontaktów ze służbą zdrowia obecnie najczęściej rekomendowane i według mnie najkorzystniejsze jest śródoperacyjne podawanie antybiotyków do komory przedniej. Zwłaszcza że w takiej sytuacji następne podania antybiotyku w postaci kropli mogą już być wykonywane samodzielnie przez pacjenta i odbywać się w domu. W przypadku zastosowania przedoperacyjnej i pooperacyjnej antybiotykoterapii w postaci kropli czas kontaktu z pacjentem będzie wydłużony, a tego chcemy teraz uniknąć. Wytyczne naukowe nie wskazują na konieczność wprowadzania jakichkolwiek modyfikacji dotyczących substancji stosowanych w antybiotykoterapii pooperacyjnej, ponieważ nie ma to wpływu na sytuację związaną z koronawirusem. 
Czy w ramach zmniejszenia ryzyka infekcyjnego zasadne wydaje się Panu Profesorowi stosowanie w operacji obuocznej dwóch różnych zestawów sterylnych?

Operacja obojga oczu wymaga zachowania szczególnego bezpieczeństwa, zwłaszcza obecnie. W przypadku operacji obuocznych musimy dbać o ten rygor, bo to zmniejsza ryzyko ewentualnych powikłań infekcyjnych. Dlatego po przeprowadzeniu operacji jednego oka przy użyciu jednego zestawu sterylnego należy zrobić przerwę, wymienić zestaw i wykonać operację na drugim oku.

Czy obecna sytuacja epidemiologiczna w jakikolwiek sposób wpłynęła na zalecenia dotyczące obecności anestezjologa przy zabiegach?

Generalnie na świecie nie ma jednego wzorca postępowania. Zagadnienie obecności anestezjologa stanowi powód dyskusji od dłuższego czasu i lekarze z różnych krajów zastanawiają się, jak ograniczyć jego obecność na okulistycznej sali operacyjnej. W Polsce nadal jednak jesteśmy zobowiązani do przestrzegania zarządzenia NFZ co do warunków przeprowadzania operacji zaćmy, które nie wyeliminowało anestezjologa z udziału w tej procedurze leczenia.

A w jakie środki ochrony osobistej powinien być wyposażony sam pacjent w trakcie pobytu na oddziale?

Poza ogólnie stosowanymi metodami nie ma dla pacjentów żadnych dodatkowych sposobów zabezpieczenia. Pacjenci zatem powinni mieć przede wszystkim maseczki. Bardzo ważne jest też podkreślanie konieczności zachowania zasad higieny, głównie mycia rąk. Ewentualnie jeśli podczas zaplanowanego badania może dochodzić do rozpylania aerozolu (dzieje się tak w badaniach wykorzystujących podmuch powietrza, który może spowodować powstanie aerozolu łez wokół oczu badanego), wówczas pacjent może założyć fartuch i rękawiczki.

Panie Profesorze, do tej pory rozmawialiśmy przede wszystkim o zapewnieniu ochrony pacjentom chirurgicznym, którzy ze względu na rodzaj procedury są najbardziej narażeni na infekcję. Teraz chciałbym zapytać, czy istnieje ryzyko zakażenia również w gabinetach. Chodzi mi tu przede wszystkim o personel i lekarzy. Czy oprócz ogólnych wytycznych, jakie obowiązują we wszystkich placówkach ochrony zdrowia, w placówkach okulistycznych są jakieś szczególne sposoby, które pomogą dodatkowo zmniejszyć to ryzyko?

Istnieją doniesienia o możliwości zakażenia koronawirusem drogą przez spojówkę. Tego typu zakażenie jest jednak rzadkie (ok. 0,8\% przypadków w jednej z grup). Dlatego nie ma specjalnych dodatkowych zaleceń. Podstawowym zabezpieczeniem jest wnikliwe przeprowadzenie wywiadu przed przyjęciem pacjenta i zmierzenie temperatury, a w przypadku wykrycia oznak wskazujących, że dana osoba może być nosicielem koronawirusa, podjęcie odpowiednich działań. Poza tym personel powinien zachowywać ogólnie przyjęte zasady bezpieczeństwa: stosować standardowe środki ochrony, jak: fartuch jednorazowy, rękawice ochronne, maseczki z klasą bezpieczeństwa FFP2 lub FFP3 lub równoważne, okulary lub przyłbice ochronne. Należy jednak zaznaczyć, że niektóre ze środków mogą utrudniać badanie pacjenta, mam na myśli np. używanie przyłbicy w trakcie badania. Bardzo ważna jest także higiena osobista związana z myciem rąk. Jak wspomniałem wyżej, zakres ochrony należy dostosować do danego przypadku. 
Na zakończenie chciałbym zapytać Pana Profesora o kilka kwestii prawnych. Jak wiadomo, pacjent przyjmowany na hospitalizację powinien zostać poinformowany o wszystkich aspektach leczenia, w tym ryzyku powikłań. Ma to na celu nie tylko dokładne zapoznanie pacjenta $\mathrm{z}$ korzyściami i ryzykiem związanym z leczeniem, lecz także zabezpiecza lekarza przed ewentualnymi pozwami. Czy uważa Pan, że w obecnie stosowanych formularzach zgody pacjenta na zabieg należy dodawać informację, że podczas pobytu w szpitalu istnieje ryzyko zakażenia koronawirusem?

Zagadnienie to pozostaje nieuregulowane w centralnych wytycznych, ale myślę, że nie ma takiej potrzeby. Informacja na temat zagrożenia i procedur jest powszechnie dostępna, a samo zagrożenie ma charakter masowy i dotyczy w podobnym stopniu wszystkich miejsc, w których następuje gromadzenie się ludzi. Przyjmując punkt widzenia, zgodnie z którym pacjent powinien być informowany o zagrożeniu zakażenia koronawirusem, powinniśmy również np. przed wejściem do sklepu podpisywać stosowne oświadczenie. Jeśli jednak dyrekcja danej placówki uważa, że taka informacja powinna znaleźć się w dokumentacji danego pacjenta, to oczywiście nie ma formalnych przeszkód przed jej wprowadzeniem. U mnie w szpitalu się tego nie robi.

A co robić, kiedy mimo wszystko dojdzie do zakażenia w placówce i pacjent będzie chcial pozwać ją lub lekarza? Czy postępowanie zgodne z zapisami stanowiska konsultanta krajowego chroni lekarza przed potencjalnym postępowaniem i odpowiedzialnością?

Pacjent może zawsze pozwać lekarza lub zawiadomić o podejrzeniu popełnienia przestępstwa. Później jednak zarzut musi zostać jednoznacznie udowodniony przez powoda. Sytuacja zarysowana w pytaniu jest bardzo ogólna. Z pewnością inaczej przebiegałoby postępowanie $w$ przypadku, gdyby sprawa dotyczyła świadomych zaniedbań, np. braku zachowania zasad higieny, a inaczej gdyby sąd musiał zdecydować, czy winny jest lekarz, który podczas badania musiał zdjąć przyłbicę. Poza tym musimy pamiętać, że każdy sędzia wydaje wyrok na podstawie własnego sumienia, więc nie da się jednoznacznie powiedzieć, jakie postępowanie skutkowałoby wymierzeniem kary, a jakie nie zostałoby potraktowane jako przestępstwo. Tak więc interpretacja danej sytuacji będzie zawsze należała do sądu.

Osobiście, gdybym był biegłym w podobnej sprawie, to przy założeniu, że zostały zachowane wszelkie wymagane zasady bezpieczeństwa, uznałbym niewątpliwie rację lekarza. Postępowanie zgodne $\mathrm{z}$ wytycznymi w takiej sytuacji należałoby określić jako dołożenie wszelkich możliwych starań i niedoprowadzenie do pogorszenia stanu zdrowia pacjenta. Pamiętajmy bowiem, że każda procedura może prowadzić do wystąpienia działań niepożądanych, a każda wizyta u lekarza w sezonie grypowym może doprowadzić do infekcji. I jest to ryzyko nierozerwalnie związane już nawet nie z samym leczeniem, ale z całym naszym życiem. Gdybyśmy chcieli uniknąć całkowicie tego typu ryzyka, powinniśmy całkowicie przestać leczyć. 
Powiedział Pan wcześniej, że mimo epidemii lekarze mają obowiązek pracować zgodnie $z$ obowiązkami nałożonymi na nich $w$ ustawie o zawodzie lekarza. Jak powinien postąpić lekarz okulista w sytuacji, gdy nie otrzyma wystarczającego wsparcia we wdrażaniu postępowania zgodnego $\mathrm{z}$ opublikowanym stanowiskiem? Czy lekarz powinien pójść na ustępstwa, czy też podjąć inne działania?

Należy dodać, że wytyczne są prawem miękkim, nie twardym. Chciałbym jeszcze raz podkreślić, że w naszej pracy musimy kierować się przede wszystkim zasadami etyki lekarskiej i postępować zgodnie z przysięgą Hipokratesa. To, że nie zostaniemy przez pracodawcę zaopatrzeni w środki ochrony, nie zwalnia nas jako lekarzy ze świadczenia usług. Jeśli uznamy, że nie zostaliśmy wystarczająco zabezpieczeni przez pracodawcę do wykonywania nałożonych przez niego obowiązków, nie możemy po prostu odmówić świadczenia usługi. Powinniśmy ją wykonać, a potem możemy zgłosić roszczenia do pracodawcy w sądzie. Ten proces reguluje ustawa o zawodzie lekarza.

Bardzo dziękuję za rozmowę.

Wywiad dla „OphthaTherapy” przeprowadził Marcin Kuźma.

Opracowanie: Kinga Olszewska, Marcin Kuźma (Medical Education) 